\title{
TEACHING PROVERBS AND SAYINGS USING INFORMATION TECHNOLOGY
}

\author{
Azizova Fotimaxon Saidbaxramovna \\ Doctor of Philosophy of Pedagogical Sciences, Department of English Language Teaching \\ Methodology, UzSWLU, Tashkent, Uzbekistan
}

Article DOI: https://doi.org/10.36713/epra9074

DOI No: 10.36713/epra9074

\begin{abstract}
The aim of the present paper is to study the proverbs and sayings of English and Uzbek languages in teaching using informational technologies. The factors linguistic and extra-linguistic character causes Proverbs and sayings with the names of animals, geographical names, and historical terms, national clothing, names of plants, colors that are opened. Because of experience of comparisons English and Uzbek proverbs and sayings through teaching.

KEYWORDS: proverbs and sayings, idiom, information technologies, exercises, internet resources
\end{abstract}

\section{DISCUSSION}

Teaching foreign languages is the teaching of free orientation in a foreign language environment and the ability to adequately respond in various situations, that is, communication. New views on learning outcomes contributed to the emergence of new technologies and the abandonment of outdated ones. But we can say with confidence that "Everything new is well forgotten old." We will develop the traditional (old) methods that have been accumulated over the years in our educational system. Innovation in education is understood as the process of improving pedagogical technologies, a set of methods, techniques and teaching aids. Today, innovative methods are widely used in the educational field. One of the types of innovative method is the use of computer technology in a foreign language lesson. Today, new methods using Internet resources are opposed to traditional teaching foreign languages. The concept of traditional is associated primarily with memorizing the rules and performing language exercises. At the present stage of development of teaching foreign languages, when choosing training, it is necessary to proceed from the characteristics of the team in which it will be used, it is necessary to take into account the personal characteristics of the students, their age, interests, level of training, the period during which training will take place, as well as the technical equipment of the educational institutions. Our task is to develop a system of exercises and individual programs using phraseological units that are used today. In the process of progress in science, technology, culture, and information technology, education becomes a necessary attribute of a person's daily life. Recently, the question of the use of new information technologies in teaching has been increasingly raised. These are not only new technologies, means but also new forms and methods of teaching, a new approach to the learning process. The main goal of teaching foreign languages is the formation and development of the communicative culture of students, teaching the practical mastery of foreign languages.

Interest in information technology is growing more and more. Today we can say with confidence that computer science and English are taught in all secondary schools, and every pupil or student can use the Internet resources.

The possibilities of using Internet resources are enormous. The global Internet (literally means "international network" - English International net) creates conditions for obtaining any information necessary for students and teachers, located anywhere in the world: regional geographic material, news from the life of youth, articles from newspapers and magazines, necessary literature etc. The use of cyberspace for educational purposes is a new direction in private methodology. 


\section{EPRA International Journal of Research and Development (IJRD)

The paramount importance is attached to understanding, conveying the content and expressing the meaning of proverbs and sayings of a foreign language. Teaching proverbs and sayings is introduced continuously, they teach proverbs in kindergarten, school, institutes and continue after graduation. We are faced with the question of how you can teach proverbs and sayings to students using information technology? We think that this is possible and convenient because it is very interesting for students to sit in front of the computer, rather than in the classroom, listening to the teacher. A list of questions appears on the computer and students must answer them within a certain time, these questions can be given in the form of tests, while students answer the tests they learn English proverbs and sayings and if you score fewer points, you can solve the problems repeatedly until you get the expected result. We have provided some examples of exercises.

1. Find equivalents to the following proverbs and sayings.

He wasn't so important in New York but is Small Ville he is a big fish in a small pond

a) An important person in a big city

b) Dangerous person in a small place

c) An important person in a small place

2. Find the proverb and saying fixed to the following sentence

I often do my homework in the evening. Sometimes I am sleepy and do not understand what I read. Then my mother tells me to go to bed and do the rest of my homework in the morning. She says:

a) Never put off till tomorrow what you can do today

b) What can be cured must be endured

c) An hour in the morning is worth two in the evening

d) Health is above wealth

3. Найдите подходящее предложение к данной пословице

The devil is not so black as is painted

a) I often do my homework in the evening. Sometimes I'm sleepy and don't understand what I read

b) I decided to paint my room and I bought black, white and brown color paints. But I didn't know painting, and my friend advised me to paint with white colour because it is the symbol of peace

c) My friend has been suffering from a bad toothache for a long time, as he is afraid to go to the dentist

4. Find right translation to the following proverb

To send owls to Athens

a) Хаёл дарёсига чўммоқ

b) Дарё бўйида қудуқ қазимоқ c) Ким табиб, бошидан ўтган табиб In addition to these tasks, you can give other tasks. For example, you can give the main word of a saying or proverb, and students will have to write a sentence. The student is invited to find proverbs on the Internet that are interesting to him and then compose his own small dictionary. For example, a student is given the task of compiling a small dictionary of proverbs and sayings in the English language with the names of animals.

A cat in gloves catches no mice

As black as a crow

He that would eat the fruit must climb the

tree neither

If you run after two hares, you will catch the hounds

One cannot run with the hare and hunt with

The early bird catches the worm

To count one's chickens before they are hatched

When the fox preaches, take care of your goose

You cannot judge a tree by its bark

Other example, giving students assignments, preparing a presentation on a computer using video clips, or preparing a portfolio.

The virtual environment of the Internet allows you to go beyond the temporal and spatial boundaries, providing its users with the opportunity to authentically communicate with real interlocutors on topics relevant to both sides. The potential for a virtual internet environment is enormous. So, to correctly translate the English unit, you need to know the geographical environment of those people, as well as the animal world. (1.31)

Thus, we can conclude that teaching proverbs and sayings using information technology provides tremendous opportunities for the formation and development of the communicative culture of students, the practical mastery of proverbs and sayings of the English language.

\section{REFERENCE}

1. Azizova F.S. Linuakulturologicheskie osobennosti frazeologicheskix edinis angliyskogo i izbekskogo yazikov. 2021. p.31. 